\title{
Esophagus and Esophagogastric Junction Cancer PT0 TNM Finding v8
}

National Cancer Institute

\section{Source}

National Cancer Institute. Esophagus and Esophagogastric Junction Cancer pTO TNM

Finding v8. NCI Thesaurus. Code C133375.

Esophagus and esophagogastric junction cancer with no evidence of primary tumor.

(from AJCC 8th Ed.) 